\title{
POTENSI ENERGI TAHUNAN PEMBANGKIT LISTRIK TENAGA MIKRO HIDRO (PLTMH) BERDASARKAN SIMULASI WAKTU DI SUNGAI KEDUNG PASANG KABUPATEN PACITAN
}

\author{
Muhammad Abi Rafdi 1), Rintis Hadiani 2), Solichin 2) \\ 1) Mahasiswa Fakultas Teknik, Prodi Teknik Sipil, Universitas Sebelas Maret \\ 2) Pengajar Fakultas Teknik, Prodi Teknik Sipil, Universitas Sebelas Maret \\ Jl. Ir. Sutami 36A, Surakarta 57126; Telp.0271-634524. Email: abi.rafdi.911@gmail.com
}

\begin{abstract}
Abstrak
Pembangkit Listrik Tenaga Mikro Hidro (PLTMH) adalah salah satu sumber energi alternatif yang ramah lingkungan serta relatif mudah untuk direalisasikan. Sejak tahun 1994, di Desa Nawangan, Kabupaten Pacitan terdapat PLTMH yang telah beroperasi, namun energi yang dihasilkan tidak mampu memenuhi kebutuhan pada saat musim kering terjadi, dan komponen PLTMH yang mengalami kerusakan telah menyebabkan penurunan tingkat efisiensi dan keandalan. Untuk mengatasi masalah tersebut akan dikaji ulang perhitungan potensi energi berdasarkan simulasi waktu operasional dan musim. Penelitian ini bertujuan untuk mengetahui besarnya potensi energi tahunan PLTMH berdasarkan debit andalan Q80, Q70, Q50 dan Q30, perbedaan potensi energi antara sebelum dan sesudah simulasi waktu serta memperoleh waktu operasi efektif PLTMH. Setelah merekapitulasi data hujan dan menguji konsistensi data hujan dengan metode analisis kurva linier massa ganda, evapotranspirasi dihitung menggunakan software Cropwat, debit sepanjang tahun dihitung dengan metode F.J Mock, kemudian debit andalan dihitung dengan metode Basic Year. Perhitungan potensi energi didapatkan dari pengolahan hasil survey kondisi eksisting PLTMH yaitu pengukuran bangunan eksisting serta tinggi jatuh (head) dan kemudian dihitung dengan rumus potensi energi secara fisika. Berdasarkan perhtiungan, diperoleh nilai potensi energi tahunan PLTMH berdasarkan debit andalan Q80, Q70, Q50, dan Q30 beruturut-turut sebesar 116342,516 kWh; 121531,367 kWh; 130339,711kWh dan 128310,412 kWh. Setelah potensi energi dihitung menggunakan simulasi waktu operasional, diperoleh nilai potensi energi beruturut-turut 92856,543 kWh; 98054,552 kWh; 115669,809 kWh dan 104217,597 kWh. Sedangkan potensi energi berdasarkan simulasi musim diperoleh 92128,858 kWh; 97770,770 kWh; 105573.01 kWh dan 103134,641 kWh. Untuk waktu operasional efektif PLTMH ditetapkan berdasarkan perhitungan energi dari debit andalan Q80 dengan simulasi waktu operasional yaitu PLTMH aktif pada 15 hari ke 1-13 (1 Januari - 15 Juli) kemudian dinonaktifkan pada 15 hari ke 14 22 (16 Juli-30 November) untuk keperluan maintenance, dan diaktifkan kembali pada 15 hari ke 23-24 (1-31 Desember).
\end{abstract} Kata kunci : PLTMH, debit andalan, potensi energi, simulasi waktu, waktu operasional, maintenance

\begin{abstract}
Microbydro Powerplant (PLTMH) is one of many environment friendly energy source and it is easy to build. Since 1994, in Nawangan Village, Pacitan regency there is a microbydro powerplant that was operating but the energy output was unable to meet the energy needs during dry season, and the powerplant damaged component has resulted in a decrease both in efficiency and reliability level. To overcome the problem, will be reviewed the calculation of energy potential based on simulation of operational time and season. This study aims to determine the amount of yearly energy potential of microbydro powerplant based on the dependable discharge of Q80, Q70, Q50, and Q30 and the energy potential difference between before and after the time-based simulation to obtain effective operating time of the microbydro powerplant. After the calculation of the rainfall data and testing the data consistency with double mass liner curve method, the ervapotranspiration calculated using Cropwat software, then the yearly discharge were calculated using F.J Mock method. Calculation of energy potential obtained from the processing of survey results of the microbydro powerplant existing conditions, such as the existing building measurement and the falling height (head) and then calculated using physical energy potential formula. Based from the calculation, obtained the value of the microbydro powerplant energy potential based on the dependable discharge of Q80, Q70, Q50, and Q30 are $116342.516 \mathrm{kWh} ; 121531.367 \mathrm{kWh} ; 130339.711 \mathrm{kWh}$ and $128310.412 \mathrm{kWh}$. After the energy potential calculated using a simulated operational time, obtained value of energy potential are $92856.543 \mathrm{~kW} \mathrm{b;} 98054.552 \mathrm{kWh;115669.809}$ $\mathrm{kWh}$ and $104217.597 \mathrm{kWh}$. . While the seasonal time-based simulation energy potential, obtained value of energy potenetial are $92128.858 \mathrm{kWh} ; 97770.770 \mathrm{kWh} ; 105573.01 \mathrm{kWh}$ and 10313.,641 kWh For the effective microbydro powerplant operational time is set based on the calculation of 280 dependable discharge, where the microbydro powerplant is active from $1^{\text {st }}$ of January to $15^{\text {th }}$ of July, then went deactivated from $16^{\text {th }}$ of July to $30^{\text {th }}$ of November for maintenance and repair, and activated again on $1^{\text {st }}$ to $31^{\text {st }}$ December.
\end{abstract}

Keywords : Microbydro powerplant, dependable discharge, energy potential, time-based simulation, maintenance 


\section{PENDAHULUAN}

Dewasa ini, keperluan akan energi untuk kelangsungan hidup sehari-hari sudah menjadi sebuah keharusan. Hal ini dikarenakan hampir semua peralatan dan kendaraan menggunakan energi untuk beroperasi, terutama energi listrik. Pada daerah Nawangan, Kabupaten Pacitan, sebagian wilayah belum mendapatkan energi listrik untuk bisa dinikmati masyarakat, telah dibangun Pembangkit Listrik Tenaga Mikro Hidro (PLTMH) pada tahun 1994 lampau dan sempat beroperasi, namun output daya pada musim kemarau tidak dapat memenuhi kebutuhan masyarakat. Pada Pembangkit Listrik Tenaga Mikro Hidro (PLTMH) ini akan dilakukan analisis potensi energi tahunan berdasarkan simulasi waktu. Energi tahunan yang dimaksud adalah total besarnya energi yang mampu dihasilkan oleh suatu unit pembangkit energi dalam kala waktu satu tahun, dimana di dalamnya terdapat beberapa variabel yang mempengaruhi seperti waktu dan kondisi operasional. Dengan tujuan untuk memperoleh hasil yang lebih mendetail, maka dilakukan simulasi waktu dengan debit andalan berdasar Q30, Q50, Q70, dan Q80. Analisis potensi energi ini sangat penting dilakukan untuk mendapatkan waktu operasi efektif (yang menghasilkan energi tertinggi) pada sistem PLTMH ini pada kurun waktu tertentu, sehingga dapat direncanakan waktu non-aktif untuk keperluan maintenance atau lainnya pada saat kurun waktu yang tidak efektif untuk beroperasi.

\section{TINJAUAN PUSTAKA DAN LANDASAN TEORI}

\section{Data Survei Lapangan}

Data lapangan didapat berdasarkan survei yang dilakukan pada tanggal 28 Februari 2013 di Pembangkit Listrik Tenaga Mikro Hidro (PLTMH) Nawangan pada pukul 10.00 - 15.00 WIB oleh Indra Bagus (2013).

Tabel 1. Dimensi dan Pengukuran Bendung

\begin{tabular}{|c|c|c|}
\hline Pengukuran & Besar & Satuan \\
\hline Tinggi Bendung & 3 & $\mathrm{~m}$ \\
\hline Lebar Bendung & 4 & $\mathrm{~m}$ \\
\hline Tinggi Jagaan Bendung Samping Kanan (y0-p)kanan & 1 & $\mathrm{~m}$ \\
\hline Tinggi Jagaan Bendung Samping Kiri (y0-p)kiri & 2,5 & $\mathrm{~m}$ \\
\hline Tinggi Sedimen 1 & 1,9 & $\mathrm{~m}$ \\
\hline Tinggi Sedimen 2 & 1,78 & $\mathrm{~m}$ \\
\hline Tinggi Sedimen 3 & 2,38 & $\mathrm{~m}$ \\
\hline Koefisien Cr & 0,9 & $\mathrm{~m}$ \\
\hline Debit Sesaat (Q) & 0,2712 & $\mathrm{~m}^{3} / \mathrm{s}$ \\
\hline
\end{tabular}

Tabel 1 menunjukkan hasil pengukuran dimensi bendung di PLTMH Nawangan.

Tabel 2. Dimensi dan Pengukuran Bak Penenang

\begin{tabular}{lrc}
\hline Pengukuran & Besar & Satuan \\
\hline Lebar & 2,8 & $\mathrm{~m}$ \\
\hline Panjang & 13,7 & $\mathrm{~m}$ \\
\hline Kedalaman & 7,5 & $\mathrm{~m}$ \\
\hline Volume & 287,7 & $\mathrm{~m}^{3}$ \\
\hline
\end{tabular}

Tabel 2 menunjukkan hasil pengukuran dimensi bak penenang di PLTMH Nawangan.

Tabel 3. Dimensi dan Pengukuran Pipa Pesat

\begin{tabular}{lrc}
\hline Pengukuran & \multicolumn{1}{c}{ Besar } & Satuan \\
\hline Panjang & 48 & $\mathrm{~m}$ \\
\hline Diameter & 0,25 & $\mathrm{~m}$ \\
\hline Material & Baja Galvalum & - \\
\hline Banyak pipa & 1 & buah \\
\hline
\end{tabular}

Tabel 3 Menunjukkan hasil pengukuran pipa pesat (penstock) di PLTMH Nawangan.

\section{Evapotranspirasi}

Evapotranspirasi akan dihitung menggunakan metode Penmann Modifikasi dengan menggunakan perangkat lunak Cropwat. 


\section{Pengisian Data Hujan yang Hilang}

Pengisian data hujan yang hilang akan dilakukan dengan metode Reciprocal, dimana metode ini dianggap lebih baik daripada metode Normal Ratio (Bambang Triatmodjo, 2006) untuk menghitung data hujan yang hilang karena memperhitungkan jarak antar stasiun (Li), dengan menggunakan persamaan (1).

$P x=\frac{\sum_{i=1}^{n} \frac{p_{i}}{L_{i}^{2}}}{\sum_{i=1}^{n} \frac{1}{L_{i}^{2}}}$

dengan:

$P_{\mathcal{X}} \quad=$ data curah hujan pada stasiun $\mathrm{X}$ yang diperkirakan data hilang,

$P_{i} \quad=$ data hujan disekitarnya pada periode yang sama,

$L_{i} \quad=$ jarak antar stasiun.

Uji Konsistensi Data Hujan

Uji konsistensi hujan yang dilakukan dalam penelitian ini menggunakan metode kurva massa ganda (Double Mass Curve) dengan persamaan (2). Model regresi dikatakan sempurna apabila $R^{2}=1$.

$R^{2}=\frac{\sum x_{y_{i}}-\sum x_{i} \sum y_{i} / n^{2}}{\sum x_{i}^{2}-\left(\sum x_{i}\right)^{2} / n\left(\sum y_{i}\right)^{2}-\left(\sum y_{i}\right)^{2} / n}$.

dengan :

$\mathrm{R}^{2} \quad=$ koefisien deterministik,

$x_{i} \quad=$ nilai kumulatif data hujan ke,

$y_{i} \quad=$ nilai kumulatif rata-rata data hujan ke,

n $\quad=$ jumlah data.

\section{Curah Hujan Wilayah}

Curah hujan wilayah pada penelitian ini dihitung menggunakan metode rata-rata aritmatik karena jarak antar stasiun hujan yang relatif dekat $(<25 \mathrm{~km})$, menggunakan persamaan (3).

$\mathrm{CH}$ rerata $=\frac{\sum \mathrm{Ri}}{n}$

dengan:

$\mathrm{CH}$ rerata $=$ curah hujan rerata $(\mathrm{mm})$,

$\mathrm{Ri} \quad=$ besarnya CH pada stasiun I $(\mathrm{mm})$,

$\mathrm{n} \quad=$ jumlah stasiun hujan.

\section{Metode F.JMock}

Metode Mock merupakan model neraca air yang dapat menghitung debit bulanan dari data curah hujan, evapotranspirasi, kelembaban tanah dan tampungan air tanah. Model neraca air Mock memberikan metode perhitungan yang relatif sederhana untuk berbagai macam komponen berdasarkan riset DAS di seluruh Indonesia (KP-01,2010).

\section{Debit Andalan}

Debit andalan adalah debit minimum sungai dengan kemungkinan debit terpenuhi dalam persentase tertentu, misalnya 90\%, 80\% atau nilai lainnya, sehingga dapat dipakai untuk kebutuhan tertentu (Departemen Energi dan Sumber Daya Mineral, 2009). Tingkat keandalan debit tersebut dapat terjadi, berdasarkan probabilitas kejadian mengikuti rumus Weibull pada persaaan (4) berikut.

$P=\frac{i}{(n+1)} \times 100 \%$

dengan:

$\mathrm{i} \quad=$ Nomor urut debit,

$\mathrm{n} \quad=$ Jumlah data,

$\mathrm{P} \quad=$ Probabilitas terjadinya kumpulan nilai yang diharapkan selama periode pengamatan $(\%)$.

\section{Metode Basic Year}

Analisis Basic Year adalah analisa perhitungan debit hujan menggunakan data rata-rata tahunan. Langkah perhitungan debit andalan menggunakan metode Basic Year sebagai berikut:

1. Mengitung data debit andalan dengan metode.

2. Data debit tahunan diurutkan dari kecil ke besar.

3. Menghitung data yang digunakan sebagai acuan perhitungan dengan persamaan (4). 


\section{Menghitung Hidrolis Pipa dan Perencanaan Kemampuan Tenaga Air}

Kerugian tinggi-tekan terdiri atas kerugian tinggi-tekan mayor dan minor, atau head losses mayor dan head losses minor. Head losses mayor disebabkan karena kerugian gesek di dalam pipa-pipa, dan head losses minor disebabkan karena kerugian di dalam belokan-belokan, reduser, katup-katup, dan sebagainya (Sularso dan Tahara, 2006).

\section{Head Losses Mayor}

Untuk menghitung kerugian gesek antara dinding pipa dengan aliran fluida tanpa adanya perubahan luas penampang di dalam pipa dapat dipakai persamaan Darcy-Weisbach pada persamaan (5) berikut.

$h f=f . L v^{2} . D 2 g$

dengan:

hf $=$ head loss mayor $(\mathrm{m})$,

$\mathrm{f}=$ koefisien gesekan,

$\mathrm{L}=$ panjang pipa $(\mathrm{m})$,

$\mathrm{D}=$ diameter dalam pipa $(\mathrm{m})$,

$\mathrm{v}=$ kecepatan aliran dalam pipa $(\mathrm{m} / \mathrm{s})$,

$\mathrm{g}=$ percepatan gravitasi $\left(\mathrm{m} / \mathrm{s}^{2}\right)$.

\section{Head Losses Minor}

Secara umum head losses minor dinyatakan pada persamaan (6) sebagai berikut.

$h=K \cdot v^{2} .2 g$

dengan:

$h=$ head loss minor,

$\mathrm{K}=$ koefisien resistansi valve atau fitting berdasarkan bentuk dan ukuran

$\mathrm{v}=$ kecepatan rata-rata aliran dalam pipa $(\mathrm{m} / \mathrm{s})$,

\section{Tinggi Netto Turbin}

Tinggi netto turbin secara umum dapat dihitung menggunakan persamaan (7) berikut ini.

Hnetto $=\mathrm{H}$ statis $-\mathrm{hf}$ total

dengan:

Hnetto = tinggi jatuh efektif (mm),

Hstatis = tinggi jatuh bruto $(\mathrm{mm})$,

Hf total $=$ tinggi jatuh dari tekanan air yang hilang $(\mathrm{mm})$.

\section{Diameter Penstock}

Menurut standar perencanaan mikro hidro diameter penstock dapat dihitung dengan persamaan (8) dan (9). Kemudian dicari nilai yang terbesar.

$\mathrm{D}=0,72 \times$ (Qandalan) 0,5

dengan :

$\mathrm{D}=$ Diameter Penstock (m),

Qandalan $=$ Debit andalan $(\mathrm{m} 3 / \mathrm{dt})$.

$$
d=2,69 x\left(\frac{n^{2} \times Q^{2} \times L}{H}\right)^{0,1875}
$$

dengan:

$\mathrm{d}=$ diameter penstock $(\mathrm{m})$

$\mathrm{n}=$ koefisien manning

$\mathrm{Q}=$ debit maksimal melewati penstock $\left(\mathrm{m}^{3} / \mathrm{dt}\right)$

$\mathrm{L}=$ panjang pipa penstock $(\mathrm{m})$

$\mathrm{H}=$ tinggi jatuh $(\mathrm{m})$

\section{Tinggi Jatuh (head)}

Tinggi jatuh yang digunakan merupakan tinggi jatuh efektif yang didapat dari tinggi jatuh bruto dikurangi tinggi jatuh dari tekanan air yang hilang Dapat dirumuskan sesuai persamaan (10) sebagai berikut.

Heff $=$ Hbruto - Hlosses ....

dengan:

Heff = tinggi jatuh efektif $(\mathrm{mm})$,

Hbruto = tinggi jatuh bruto $(\mathrm{mm})$,

Hlosses = tinggi jatuh dari tekanan air yang hilang ( $\mathrm{mm})$. 


\section{Daya yang Dapat Dihasilkan}

Daya yang dihasilkan dapat menjadi estimasi awal yang dihitung dari tinggi jatuh efektif, debit andalan dan massa jenis air dan efisiensi alat. Untuk efisiensi alat tergantung dari jenis turbin yang digunakan, sehingga untuk turbin yang berbeda akan memberikan hasil daya yang berbeda, seperti persamaan (11).

$\mathrm{P}=\eta_{t} \times \mathrm{g} \times \mathrm{Q}$ andalan $\times$ Heff

dengan:

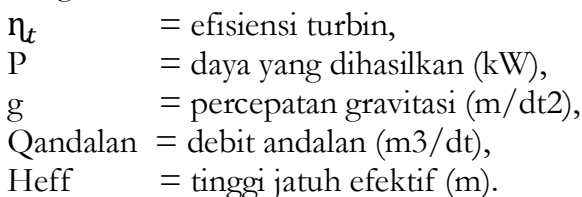

Perhitungan Potensi Energi Listrik

Energi listrik diperoleh dengan mengalikan hasil perhitungan daya listrik dengan waktu operasi PLTMH dalam periode 15 harian (360 jam), yaitu pada persamaan (12) berikut:

$\mathrm{E}=\mathrm{P} \times \mathrm{T}$

dengan:

$\mathrm{P} \quad=$ daya yang dihasilkan $(\mathrm{kW})$,

$\mathrm{T} \quad=$ waktu operasional PLTMH (jam).

\section{Simulasi Waktu}

Simulasi waktu yang digunakan sebagai dasar perhitungan di sini terdapat dua jenis, yaitu:

1. Simulasi waktu berdasarkan waktu operasional PLTMH dimana akan ditentukan dengan mampu tidaknya PLTMH memenuhi kebutuhan daya dari masyarakat Desa Nawangan. Di saat PLTMH tidak mampu memenuhi kebutuhan daya, maka PLTMH akan dinonaktifkan untuk keperluan maintenance.

2. Simulasi waktu berdasarkan interval musim. Dasar penentuan musim di sini ditentukan berdasarkan curah hujan pada interval 3 bulan. Dimana curah hujan tertinggi selama periode 3 bulan akan ditentukan sebagai musim hujan, kemudian dilanjutkan dengan interval musim berikutnya. Diperoleh empat keadaan yaitu:
a. Musim hujan,
b. Peralihan musim hujan-kemarau,
c. Musim kemarau, dan
d. Peralihan musim kemarau-hujan.

\section{METODE PENELITIAN}

Lokasi penelitian ini dilakukan di site PLTMH Sungai Kedung Pasang Desa Nawangan, Kabupaten Pacitan, Jawa Tengah. Sungai ini terletak di wilayah DAS Grindulu yang memiliki luas $24,6 \mathrm{~km}^{2}$. Data-data yang diperlukan antara lain data hujan harian tahun 2006-2015 dari tiga stasiun yang dipilih, peta DAS Grindulu skala 1:25000. Analisis data dilakukan dengan bantuan Microsoft Excel, AutoCAD dan Google Earth.

Penelitian yang pertama dilakukan adalah mengolah data survey dan data hujan, kemudian uji konsistensi data hujan yang diperoleh. Setelah itu dilakukan pengolahan data evapotranspirasi lalu dilanjutkan dengan perhitungan metode F.J Mock. Kemudian dilakukan perhitungan debit andalan metode Basic Year untuk nantinya dilakukan perhitungan potensi energi. Lalu dilakukan penentuan interval kedua simulasi waktu, dan menghitung potensi energi berdasarkan simulasi waktu. Kemudian menentukan waktu operasional efektif PLTMH.

\section{HASIL DAN PEMBAHASAN}

Data Peta Stasiun Hujan dan DAS Grindulu

Stasiun hujan yang digunakan sebagai dasar analisis adalah stasiun hujan Nawangan, Bandar, dan Arjosari.

Stasiun hujan Nawangan koordinat $8^{\circ} 2^{\prime} 7.20^{\prime \prime S}$ dan $111^{\circ} 10^{\prime} 39.26^{\prime E}$

Stasiun hujan Bandar koordinat $8^{\circ} 1^{\prime} 52.60^{\prime \prime S}$ dan $111^{\circ} 13^{\prime} 29.30^{\prime \prime E}$

Stasiun hujan Arjosari koordinat $8^{\circ} 4^{\prime} 35.80^{\prime \prime S}$ dan $111^{\circ} 9^{\prime} 54.31^{\prime \prime E}$

Jarak antar stasiun sebagai berikut:

Tabel 4 Jarak Antar Stasiun Hujan Berpengaruh (km)

\begin{tabular}{|c|ccc|}
\hline Stasiun & Nawangan & Bandar & Arjosari \\
\hline Nawangan & & 5,22 & 4,78 \\
\hline Bandar & 5,22 & & 8,28 \\
\hline Arjosari & 4,78 & 8,28 & \\
\hline
\end{tabular}

Tabel 4 menunjukkan jarak stasiun hujan yang berpengaruh, dengan jarak terjauh adalah 8,28 km. Sedangkan DAS Grindulu adalah Sub-DAS dari DAS utama Grindulu-Lorog. Luas DAS yang diperoleh dari perhitungan menggunakan perangkat lunak $A$ utoCAD adalah $24,608 \mathrm{~km}^{2}$. 


\section{Evapotranspirasi}

Data evapotranspirasi yang digunakan adalah hasil pengolahan dari data klimatologi Kabupaten Magetan yang diperoleh dari Dinas Navigasi Udara dan Badan Meteorologi TNI-AU. Dikerjakan menggunakan software Cropwat 8.0

\section{Data Hujan}

Data hujan harian yang digunakan diperoleh dari stasiun hujan Nawangan, Bandar, dan Arjosari dari tahun 2006 hingga tahun 2015. Dari data hujan harian dari stasiun kemudian direkapitulasi dalam bentuk data hujan 15 harian, yang akan digunakan untuk perhitungan hujan wilayah dengan ,metode rata-rata aritmatik.

\section{Pengisian Data Hujan yang Hilang}

Data hujan yang hilang diisi dengan menggunakan metode reciprocal. Pada penilitian ini diperoleh kehilangan data hujan pada bulan Desember 2009 dan Januari 2010 dari stasiun hujan Bandar.

\section{Uji Konsistensi Data Hujan}

Uji konsistensi data hujan pada penelitian ini digunakan metode analisis kurva massa ganda.

\section{Perhitungan Grafik Hubungan Curah Hujan dan Hari Hujan}

Setelah mengetahui curah hujan wilayah, maka dilakukan perhitungan untuk grafik hubungan curah hujan dan hari hujan. Jumlah hari hujan direkapitulasi menjadi periode tiap 15 hari.

\section{Perhitungan Transformasi Hujan - Debit dengan Metode F.J Mock}

Pada perhitungan ini sebelumnya telah diketahui data parameter yang akan digunakan dalam proses perhitungan sesuai dengan KP-01 sebagai berikut.

Tabel 5. Data Parameter DAS Grindulu

\begin{tabular}{lll}
\hline No & Parameter & Nilai \\
\hline $\mathbf{1}$ & Catchment Area (Luas DAS) $\left(\mathrm{km}^{2}\right)$ & 24,60852 \\
\hline $\mathbf{2}$ & SMC $(\mathrm{mm})$ & 200 \\
\hline $\mathbf{3}$ & $\mathrm{k}$ & 0,8 \\
\hline $\mathbf{4}$ & $\mathrm{I}$ & 0,2 \\
\hline
\end{tabular}

Sumber: BBWS Bengawan Solo

Perhitungan metode Mock dilakukan terhadap data hujan 15 harian selanjutnya dengan tahapan yang sama, perhitungan dilanjutkan hingga tahun 2015. Kemudian menghitung korelasi antara Water Surplus dan Run Offuntuk kontrol hasil perhitungan.

Tabel 6. Kontrol Perhitungan Metode Mock

\begin{tabular}{|c|cc|c|cc}
\hline Tahun & Korelasi WS-RO & Keterangan & Tahun & Korelasi WS-RO & Keterangan \\
\hline $\mathbf{2 0 0 6}$ & 0.998 & Ok & 2011 & 0.998 & Ok \\
\hline $\mathbf{2 0 0 7}$ & 0.996 & Ok & 2012 & 0.997 & Ok \\
\hline $\mathbf{2 0 0 8}$ & 0.998 & Ok & 2013 & 0.998 & Ok \\
\hline $\mathbf{2 0 0 9}$ & 0.994 & Ok & 2014 & 0.997 & Ok \\
\hline $\mathbf{2 0 1 0}$ & 0.996 & Ok & 2015 & 0.999 & Ok \\
\hline
\end{tabular}

Tabel 6 menunjukkan hasil perhitungan nilai korelasi antara Water Surplus dan Run Off, diperoleh nilai korelasi mendekati 1, maka perhitungan metode F.J Mock dinyatakan benar.

Analisis Debit Andalan Metode Basic Year

Debit andalan yang digunakan yaitu debit andalan dengan probabiltas 80\% (Q80), 70\% (Q70), 50\% (Q50) dan 30\% (Q30). Setelah mengurutkan debit dari kecil ke besar kemudian menentukan tahun debit andalan yang akan digunakan sebagai dasar perencanaan dengan rumus probabilitas $W$ eibull.
1. Untuk Q80 $=\frac{10}{\frac{100 \%}{(100 \%-80 \%)}}+1$
$=3$ (Tahun 2006)
2. Untuk Q70 $=\frac{10}{\frac{100 \%}{(100 \%-70 \%)}}+1$
$=4$ (Tahun 2014)
3. Untuk Q50 $=\frac{10}{\frac{100 \%}{(100 \%-50 \%)}}+1$

$$
=6 \text { (Tahun 2007) }
$$
4. Untuk Q30 $=\frac{10}{\frac{100 \%}{(100 \%-30 \%)}}+1$
$=8$ (Tahun 2017

Selanjutnya, dengan menggunakan setiap tahun dari debit probabilitas tersebut akan dilakukan perhitungan potensi daya dan energi dari PLTMH Nawangan. 


\section{Perhitungan Komponen Bangunan PLTMH Eksisting}

Penstock (Pipa Pesat)

Pada pipa pesat akan dilakukan perhitungan debit maksimal yang dapat melewati pipa pesat. Dengan mengetahui data pengukuran pipa pesat, debit maksimal yang melalui pipa pesat ini dihitung dengan 2 rumus yaitu pada persamaan (8) dan (9), yaitu:

1. Rumus 1

$$
\begin{aligned}
\text { Qmaks } & =\left(\frac{D}{0,72}\right)^{2} \\
\text { Qmaks } & =\left(\frac{0,25}{0,72}\right)^{2} \\
\text { Qmaks } & =0,121 \mathrm{~m}^{3} / d t
\end{aligned}
$$

2. Rumus 2

$$
\begin{aligned}
& D=2,69 \times\left(\frac{n^{2} \times Q^{2} \times L}{H}\right)^{0,1875} \\
& 0,25=2,69 \times\left(\frac{0,009^{2} \times Q^{2} \times 48}{18,361}\right)^{0,1875} \\
& \text { Qmaks }=0,121 \mathrm{~m}^{3} / \mathrm{dt}
\end{aligned}
$$

Diperoleh hasil perhitungan debit maksimal melalui pipa pesat yang sama, maka dinyatakan sebagai berikut.

Jika $Q_{\text {andalan }}>Q_{\text {maks pipa }}$ maka yang dipakai adalah Qmaks pipa,

Jika $Q_{\text {andalan }} \leq Q_{\text {maks pipa }}$ maka yang dipakai Qandalan.

\section{Perhitungan Tinggi Jatuh Efektif $\left(\mathrm{H}_{\mathrm{eff}}\right)$}

Tinggi jatuh yang digunakan adalah tinggi jatuh efektif (Heff) yang diperoleh dari tinggi jatuh bruto (Hbruto) dikurangi tinggi jatuh dari tekanan air yang hilang. Perhitungan tinggi jatuh efektif adalah sebagai berikut.

1. Luas lingkaran pipa $(\mathrm{A})=\frac{1}{4} \times 3,14 x d^{2}=\frac{1}{4} \times 3,14 \times 0,25^{2}=0,0491 \mathrm{~m}^{2}$

2. Kecepatan Aliran (v) $=\frac{Q_{80}}{A}=\frac{0,121}{0,0491}=2,4551 \frac{m}{d t}$

3. Percepatan gravitasi $(\mathrm{g})=9,81 \mathrm{~m}^{2} / \mathrm{dt}$, Koefisien Darcy-Weisbach $(\mathrm{f})=0,003$, Koefisien bentuk ujung pipa $(\mathrm{k})=0,5$

4. Kehilangan energi primer (mayor losses), perhitungan dengan persamaan (5).

$$
h f_{1}=f \times \frac{L v^{2}}{D \times 2 g}=0,003 \times \frac{48 \times 2,4551^{2}}{0,25 \times 2 \times 9,81}=0,177 \mathrm{~m}
$$

5. Kehilangan energi pada awal pipa, perhitungan dengan persamaan (6).

$$
h f_{2}=k x \frac{v^{2}}{2 g}=k x \frac{2,4551^{2}}{2 g}=0,1536 \mathrm{~m}
$$

6. Tinggi jatuh $\left(H_{e f f}\right)$

$$
\text { Heff }=\text { Hbruto }-(\text { hf } 1+\text { hf } 2)=18,361 \mathrm{~m}-(0,17696+0,1536)=18,03 \mathrm{~m}
$$

Untuk bangunan bendung dan bak penenang eksisting, tidak dilakukan perhitungan lebih lanjut karena hanya sebatas pengukuran volume dan tata letak bangunan.

\section{Perhitungan Potensi Energi \\ Perhitungan Daya}

Daya listrik yang dihasilkan dapat dihitung berdasarkan persamaan (11). Nilai $\eta_{t}$ berkisar antara 0,8 - 0,95. Karena turbin eksisting merupakan turbin lama dan telah dipakai makan nilai $\eta_{\mathrm{t}}$ ditentukan sebesar $=0,8$ :

$$
\begin{aligned}
& P=\eta_{t} \times g \times Q_{\text {andalan }} \times H_{\text {eff }} \\
& P=0,8 \times 9,81 \times 0,121 \times 18,03 \\
& P=17,12 \mathrm{~kW} .
\end{aligned}
$$

\section{Perhitungan Potensi Energi Listrik}

Energi listrik diperoleh dengan mengalikan hasil perhitungan daya listrik dengan waktu operasi PLTMH dalam periode 15 harian (360 jam), yaitu sebagai berikut:
$\mathrm{E}=\mathrm{P} \times \mathrm{T}$
$\mathrm{E}=17,12 \times 360$
$\mathrm{E}=6163,045 \mathrm{kWh}$.

\section{Perhitungan Beban Energi Listrik}

Beban energi listrik diperoleh dengan mengalikan beban daya listrik dengan jumlah KK dan waktu operasional PLTMH.

$$
\begin{aligned}
& \mathrm{E}_{\text {beban }}=\mathrm{P} \times \mathrm{T} \times \mathrm{n} \\
& \mathrm{E}_{\text {beban }}=240 \times 360 \times 60 \\
& \mathrm{E}_{\text {beban }}=5184 \mathrm{kWh} .
\end{aligned}
$$


Hasil perhitungan untuk Q80 ditampilkan dalam grafik berikut.

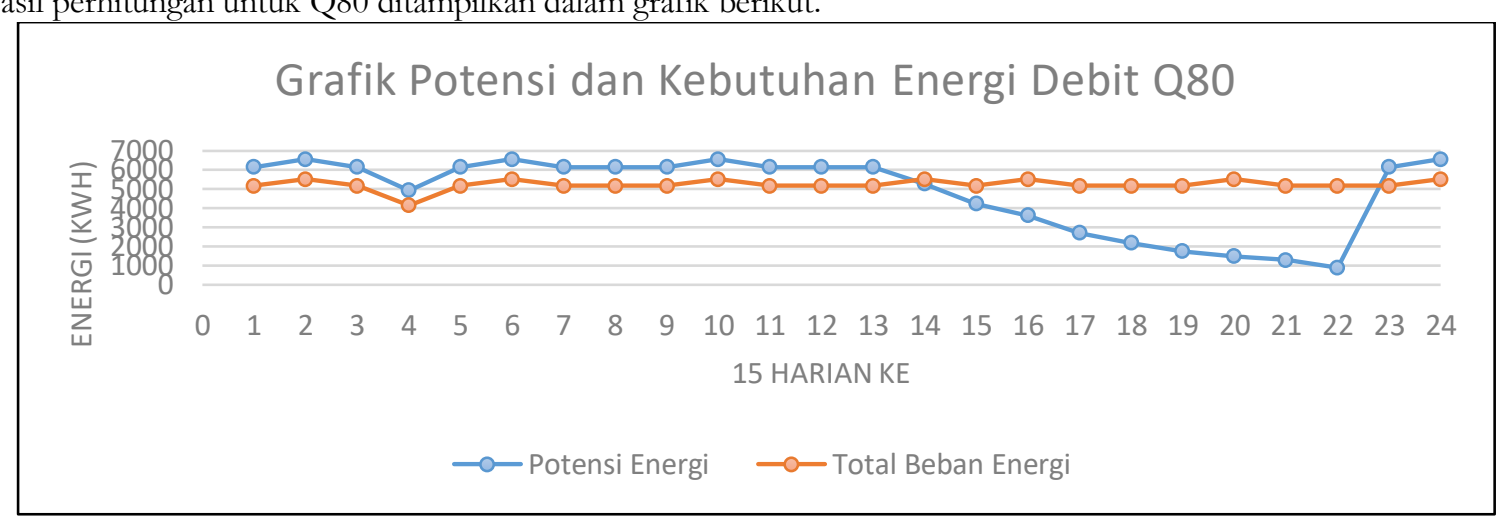

Gambar 1. Grafik Potensi dan Kebutuhan Energi Debit Q80

Pada Gambar 1 ditunjukkan mulai pada 15 harian ke-14 hingga 15 harian ke-22 PLTMH tidak mampu memenuh kebutuhan energi, sehingga selanjutnya akan dinonaktifkan untuk kegiatan maintenance. Kemudian akan dihitung potensi energi sebelum dan sesudah PLTMH dinonaktifkan.

\section{Potensi Energi Tahunan Berdasar Simulasi Waktu Operasional}

Dari Gambar 2 telah diperoleh waktu operasional PLTMH dengan debit Q80 sebagaimana tertera di atas. Untuk rekapitulasi waktu operasional selengkapnya dapat dilihat pada Tabel 7 di bawah ini.

Tabel 7 Rekapitulasi Waktu Operasional PLTMH

\begin{tabular}{|c|c|c|c|c|}
\hline No & Debit Andalan & Waktu Aktif & Waktu Nonaktif & Jumlah Hari Aktif \\
\hline \multirow[t]{2}{*}{1} & \multirow[t]{2}{*}{ Q80 } & 15 hari ke 1-13 (Jan-Juli) & 15 harian ke $14-22$ & \multirow{2}{*}{227 hari } \\
\hline & & 15 hari ke 23-24 (Desember) & (Agustus-November) & \\
\hline \multirow[t]{2}{*}{2} & \multirow[t]{2}{*}{ Q70 } & 15 hari ke 1-13 (Jan-Juli) & 15 harian ke $14-21$ & \multirow{2}{*}{242 hari } \\
\hline & & 15 hari ke 22-24 (Nov-Des) & (Agustus-November) & \\
\hline \multirow[t]{2}{*}{3} & \multirow[t]{2}{*}{ Q50 } & 15 hari ke 1-14 (Jan-Juli) & 15 harian ke $15-19$ & \multirow{2}{*}{288 hari } \\
\hline & & 15 hari ke $20-24$ (Okt-Des) & (Agustus-Oktober) & \\
\hline \multirow[t]{2}{*}{4} & \multirow[t]{2}{*}{ Q30 } & 15 hari ke 1-13 (Januari-Juli) & 15 harian ke $14-20$ & \multirow{2}{*}{257 hari } \\
\hline & & 15 hari ke 21-24 (Nov-Des) & (Agustus-Oktober) & \\
\hline
\end{tabular}

Selanjutnya, pada saat waktu non-aktif tersebut, maka potensi energi dianggap 0 , sehingga terjadi perubahan potensi energi total tahunan. Ditampilkan dalam grafik berikut.

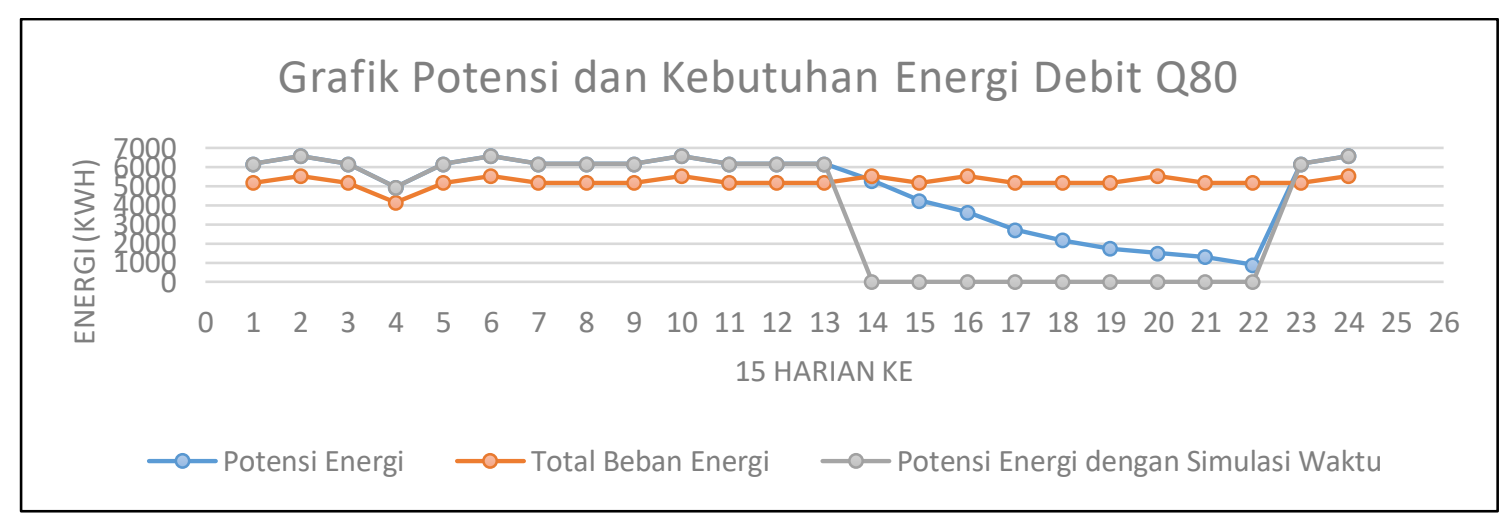

Gambar 2. Grafik Potensi dan Kebutuhan Energi Debit Q80 dengan Simulasi Waktu Operasional

Pada Gambar 2 ditunjukkan PLTMH telah dinonaktifkan pada saat tidak mampu memenuhi kebutuhan energi. Selanjutnya dilakukan perhitungan potensi energi dengan keadaan PLTMH dinonaktifkan. Disajikan pada Tabel 8.

Tabel 8. Perbedaan Potensi Energi Tahunan Sebelum dan Sesudah Simulasi Waktu Operasional

\begin{tabular}{cccc}
\hline Debit Andalan & Sebelum Simulasi $(\mathrm{kWh})$ & Sesudah Simulasi $(\mathrm{kWh})$ & Selisih $(\mathrm{kWh})$ \\
\hline Q80 & 116342.516 & 92856.543 & 23485.973 \\
\hline Q70 & 121531.367 & 98054.552 & 23476.814 \\
\hline Q50 & 130339.711 & 115669.809 & 14669.902 \\
\hline Q30 & 128310.412 & 104217.597 & 24092.814 \\
\hline
\end{tabular}


Tabel 8 menunjukkan hasil perhitungan potensi energi PLTMH sebelum dan setelah dilakukan simulasi waktu operasional, dengan selisih potensi energinya pada masing-masing debit perencanaan yang digunakan.

\section{Potensi Energi Tahunan Berdasarkan Simulasi Waktu Musim}

Interval musim yang ditentukan berdasarkan curah hujan pada tahun dasar perencanaan. Diperoleh hasil berikut:

1. Bulan Januari-Maret sebagai musim hujan (interval 1)

2. Bulan April-Juni sebagai peralihan musim hujan-kemarau (interval 2)

3. Bulan Juli-September sebagai musim kemarau (interval 3)

4. Bulan Oktober-Desember sebagai peralihan musim kemarau-hujan (interval 4)

Hasil perhitungan potensi energi berdasarkan interval musim disajikan dalam Tabel 9 berikut.

Tabel 9. Potensi Energi Tahunan berdasarkan Simulasi Waktu Musim

\begin{tabular}{ccccc}
\hline \multirow{2}{*}{ Probabilitas Debit } & \multicolumn{4}{c}{ Besar Potensi Energi $(\mathrm{kWh})$} \\
\cline { 2 - 5 } & Hujan & Hujan-Kemarau & Kemarau & Kemarau-Hujan \\
\hline Q80 & 36567 & 37389.139 & 0 & 18172.3202 \\
\hline Q70 & 36567 & 37389.139 & 0 & 24779.2667 \\
\hline Q50 & 36567 & 37389.139 & 0 & 32581.5069 \\
\hline Q30 & 36567 & 37389.139 & 0 & 30143.1377 \\
\hline
\end{tabular}

Tabel 9 menunjukkan hasil perhitungan potensi energi PLTMH pada tiap musim. Pada musim kemarau PLTMH dinonaktifkan sehingga nilai potensi energi adalah 0 . Hasil perbandingan potensi energi sebelum dan sesudah simulasi waktu musim disajikan pada Tabel 10.

Tabel 10. Perbandingan Potensi Energi Sebelum dan Sesudah Simulasi Waktu Musim

\begin{tabular}{cccc}
\hline Debit Andalan & Sebelum Simulasi $(\mathrm{kWh})$ & Sesudah Simulasi $(\mathrm{kWh})$ & Selisih $(\mathrm{kWh})$ \\
\hline Q80 & 92128.86 & 116342.52 & 24213.65 \\
\hline Q70 & 97770.77 & 121531.37 & 23760.59 \\
\hline Q50 & 105573.01 & 130339.71 & 24766.70 \\
\hline Q30 & 103134.64 & 128310.41 & 25175.77 \\
\hline
\end{tabular}

Tabel 10 menunjukkan hasil perhitungan potensi energi PLTMH sebelum dan setelah dilakukan simulasi waktu musim, dengan selisih potensi energinya pada masing-masing debit perencanaan yang digunakan. Untuk grafik potensi dan kebutuhan energi berdasarkan simulasi waktu musim untuk Q80 disajikan dalam Gambar 3 berikut ini.

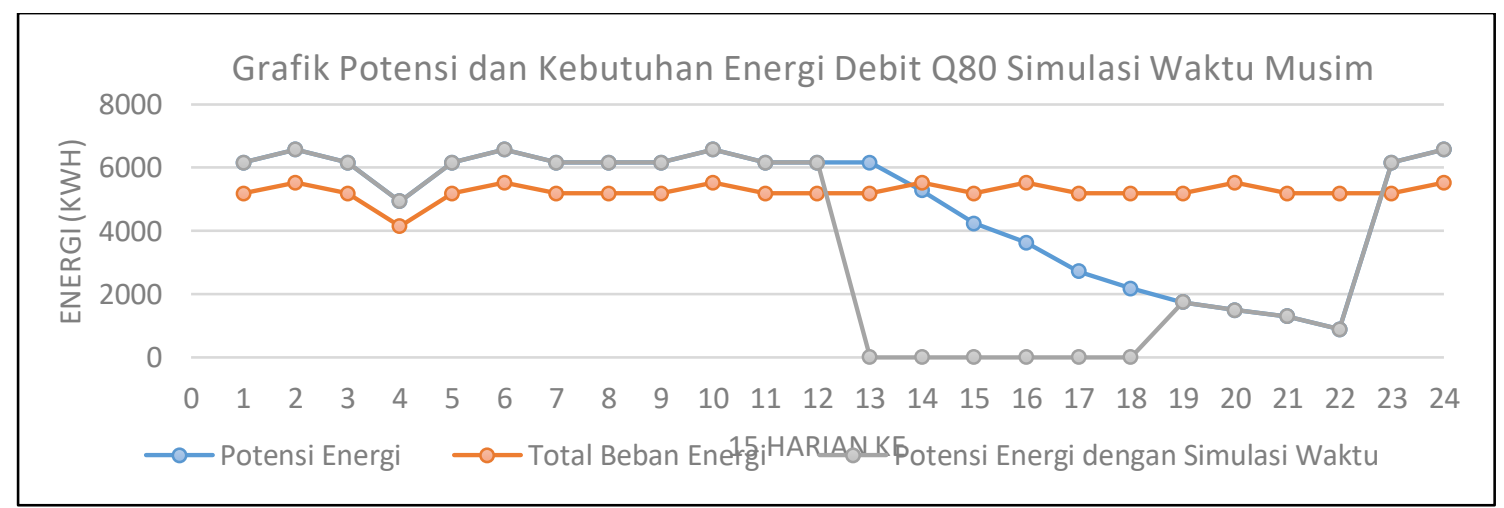

Gambar 3. Grafik Potensi dan Kebutuhan Energi Debit Q80 dengan Simulasi Waktu Musim

Pada Gambar 3 ditunjukkan potensi dan kebutuhan energi debit Q80 simulasi waktu musim pada 15 harian ke-13 PLTMH sudah mulai di nonaktifkan, padahal berdasarkan hasil perhitungan potensi energi PLTMH masih mampu memenuhi kebutuhan listrik masyarakat Desa Nawangan. Sedangkan pada 15 harian ke-19 hingga 22, PLTMH tidak mampu memenuhi kebutuhan listrik masyarakat, namun PLTMH diaktifkan karena menurut hasil penentuan interval musim kemarau telah selesai. Hal ini akan berdampak kepada sistem mekanikal dan elektrikal PLTMH, dimana seharusnya apabila PLTMH sudah tidak mampu memenuhi kebutuhan listrik masyarakat, harus segera dinonaktifkan untuk kebutuhan maintenance. 


\section{Penentuan Waktu Operasional PLTMH}

Ditetapkan bahwa waktu operasional PLTMH yang dipakai adalah waktu operasional berdasarkan perhitungan potensi energi dengan debit andalan Q80, yaitu:

1. Masa aktif pertama PLTMH mulai tanggal 1 Januari (15 harian ke 1) hingga tanggal 15 Juli (15 harian ke 13),

2. Kemudian PLTMH dinonaktifkan tanggal 16 Juli (15 harian ke 14) hingga 30 November (15 harian ke 22),

3. PLTMH diaktifkan kembali tanggal 1 Desember (15 harian ke 23) hingga tanggal 31 Desember (15 harian ke 24).

4. PLTMH memiliki total masa aktif PLTMH 227 hari dengan potensi energi sebesar 92856,543 $\mathrm{kWh}$ dalam satu tahun.

\section{KESIMPULAN}

Berikut adalah kesimpulan yang dapat diambil dari penelitian ini, antara lain:

1. Besar debit andalan sungai berdasarkan probabilitas adalah sebagai berikut:
a. $\mathrm{Q} 80=0,852 \mathrm{~m}^{3} / \mathrm{dt}$
c. $\mathrm{Q} 50=1,085 \mathrm{~m}^{3} / \mathrm{dt}$
b. $\mathrm{Q} 70=0,864 \mathrm{~m}^{3} / \mathrm{dt}$
d. $\mathrm{Q} 30=1,118 \mathrm{~m}^{3} / \mathrm{dt}$

2. Besar potensi energi yang mampu dihasilkan oleh PLTMH berdasarkan debit andalan diatas adalah sebagai berikut:
a. Potensi Energi Q80 = 116342,516 kWh
c. Potensi Energi Q50 = 130339,711 kWh
b. Potensi Energi Q70 = 121531,367 kWh
d. Potensi Energi Q30 = 128310,412 kWh

3. Besar potensi energi yang dihasilkan PLTMH berdasarkan simulasi waku adalah sebagai berikut:

Tabel 8. Perbedaan Potensi Energi Tahunan Sebelum dan Sesudah Simulasi Waktu Operasional \begin{tabular}{llll}
\hline Debit Andalan & Sebelum Simulasi (kWh) & Sesudah Simulasi $(\mathrm{kWh})$ & Selisih $(\mathrm{kWh})$ \\
\hline
\end{tabular}

\begin{tabular}{llcc}
\hline Q80 & 116342.516 & 92856.543 & 23485.973 \\
\hline Q70 & 121531.367 & 98054.552 & 23476.814 \\
\hline Q50 & 130339.711 & 115669.809 & 14669.902 \\
\hline Q30 & 128310.412 & 104217.597 & 24092.814 \\
\hline
\end{tabular}

Tabel 10. Perbandingan Potensi Energi Sebelum dan Sesudah Simulasi Waktu Musim

\begin{tabular}{cccc}
\hline Debit Andalan & Sebelum Simulasi $(\mathrm{kWh})$ & Sesudah Simulasi $(\mathrm{kWh})$ & Selisih $(\mathrm{kWh})$ \\
\hline Q80 & 92128.86 & 116342.52 & 24213.65 \\
\hline Q70 & 97770.77 & 121531.37 & 23760.59 \\
\hline Q50 & 105573.01 & 130339.71 & 24766.70 \\
\hline Q30 & 103134.64 & 128310.41 & 25175.77 \\
\hline
\end{tabular}

4. Digunakan waktu operasional berdasarkan perhitungan debit andalan Q80 (KP-01). Yaitu:

a. Masa aktif pertama PLTMH mulai tanggal 1 Januari (15 harian ke 1) hingga tanggal 15 Juli (15 harian ke 13),

b. Kemudian PLTMH dinonaktifkan mulai tanggal 16 Juli (15 harian ke 14) hingga 30 November (15 harian ke 22) untuk kebutuhan maintenance dan reparasi,

c. PLTMH diaktifkan kembali tanggal 1 Desember (15 harian ke 23) hingga tanggal 31 Desember (15 harian ke 24), kemudian berlanjut ke tahun berikutnya.

d. PLTMH memiliki total masa aktif PLTMH 227 hari dengan potensi energi sebesar 92856,543 kWh dalam satu tahun.

\section{DAFTAR PUSTAKA}

[1] Anonim. 2009. Buku 2B Pedoman Kelayakan Sipil. Jakarta: Direktorat Jendral Listrik dan Pemanfaatan Energi Departemen Energi dan Sumber Daya Mineral.

[2] Anonim. 2010. Standar Perencaan Irigasi Kriteria Perencanaan Bagian Saluran Irigasi KP-01. Jakarta: Direktorat Jendral Sumber Daya Air Departemen Pekerjaan Umum.

[3] Anonim. 2016. Data Hujan Stasiun Hujan Nawangan, Stasiun Hujan Bandar, Stasiun Hujan Arjosari 2006-2015. Surakarta: BBWS Bengawan Solo.

[4] Anonim. 2016. Peta DAS Sungai Bengawan Solo. Surakarta: BBWS Bengawan Solo.

[5] Anonim. 2016. Data Klimatologi Kabupaten Magetan Tabun 2005-2016. Magetan: Dinas Navigasi Udara dan Badan Meteorologi TNI-AU.

[6] Bambang Triatmodjo. 2009. Hidrologi Terapan. Beta Offset, Yogyakarta.

[7] Bambang Triatmodjo. 1996. Hidrolika I. Beta Offset, Yogyakarta.

[8] Indra Bagus. 2013. Revitalisasi Pembangkit Listrik Tenaga Mikro Hidro (PLTMH) Nawangan Pacitan. Jurnal. Tugas Akhir. Bambang Triatmodjo. 2006. Hidrologi Terapan. Beta Offset, Yogyakarta.

[9] Lutfi Chandra. 2014. Peningkatan Daya Listrik Pembangkit Listrik Tenaga Mikrohidro Desa Tokawi Kabupaten Pacitan. Jurnal. Tugas Akhir.

[10] Sularso dan Tahara. 2006. Pompa dan Kompresor. Jakarta: PT Pradnya Paramitha. 